Research Article

\title{
The Side Effects of Intra-cesarean Intrauterine Contraception: A Descriptive Study
}

\author{
Efek Samping Pemasangan Alat Kontrasepsi dalam Rahim (AKDR) Intrasesarea: \\ Suatu Studi Deskriptif
}

\author{
Karol A Rumopa, John Wantania, Joice Sondakh \\ Department of Obstetrics and Gynecology \\ Faculty of Medicine Universitas Sam Ratulangi/ \\ Prof. Dr. R. D. Kandou General Hospital \\ Manado
}

\begin{abstract}
Objective: To investigate the side effects and acceptance of intracesarean Intrauterine Device (IUD) insertion.

Methods: This was a descriptive study. Subjects were all pregnant women who had $\mathrm{Cu}$ T380A IUD to be placed after cesarean delivery at Prof. Dr. dr. R. D. Kandou Hospital during the period between August 2016 and September 2016.

Results: A total of 52 subjects were recruited in this study. 43 $(82.69 \%)$ subjects were in the age group of $20-30$ years. 51 of the subjects accepted the IUD. On the 7th day, $49(94.23 \%)$ and 51 $(98.07 \%)$ subjects complained of abdominal pain and vaginal bleeding, respectively, while on the $14^{\text {th }}$ day, $48(92.3 \%)$ and $50(96.1 \%)$ subjects had abdominal pain and vaginal bleeding, respectively. There were significant decreases in both complaints on the $14^{\text {th }}$ day, compared to the 7 th day. $(p<0.05$ and $p<0.05$, respectively). 51 (98.07\%) subjects accepted the IUD. There were no significant difference between acceptance on day 7 and $14^{\text {th }}$ $(\mathrm{p}>0.05)$.

Conclusion: The acceptance of side effects by the acceptor reaches $100 \%$, with the incidence of early postpartum expulsion is $3.8 \%$. The side effects of IUD are minimal.

[Indones J Obstet Gynecol 2017; 5-3: 139-141]

Keywords: intra-cesarean, intrauterine device, side effects
\end{abstract}

\begin{abstract}
Abstrak
Tujuan: Mengetahui keluhan efek samping yang ditimbulkan serta penerimaan IUD intra-sesarea pada awal masa nifas di RSUD Prof. Dr. R.D. Kandou Manado.

Metode: Penelitian ini merupakan studi deskriptif. Sampel penelitian adalah seluruh perempuan hamil yang intrasesarea di RSU Prof. Dr. dr. R.D. Kandou selama periode Agustus 2016 - September 2016.

Hasil: Jumlah sampel sebanyak 52 orang, terbanyak pada perempuan usia 20 - 35 tahun yaitu 43 perempuan (82,69\%). Penerimaan terhadap efek samping diobservasi pada hari ke 7 dan hari ke 14. Sebanyak 51 responden menerima efek samping IUD sedangkan hanya terdapat 2 responden yang tidak menerima efek samping IUD. Didapatkan perbedaan penurunan yang bermakna untuk keluhan nyeri perut pada observasi hari ke 7 dan hari ke 14, sedangkan perdarahan bercak masih didapatkan pada 50 kasus, hingga hari ke 14 pengamatan. Ekspulsi hingga hari ke 14 terjadi pada 2 kasus.

Kesimpulan: Efek samping perdarahan dan nyeri perut didapatkan minimal dengan kejadian ekspulsi awal nifas sebesar 3,8\%. Di luar kasus ekspulsi, penerimaan akseptor mencapai 100\%.

[Maj Obstet Ginekol Indones 2017; 5-3: 139-141]

Kata kunci: alat kontrasepsi dalam rahim, efek samping, intrasesarea
\end{abstract}

\section{INTRODUCTION}

Family planning permits people to accomplish their desired number of children and determine the spacing of pregnancies. The National Family Planning Coordinating Board (BKKBN) did campaigns for long-term contraceptive methods such as of intrauterine device (IUD) as a strategy to reduce mortality rate, which was one of the targets of Millenium Development Goals (MDGs) 2015. IUD is an effective long-term contraceptive method compared to other contraceptions, particularly when inserted immediately after delivery, including after cesarean delivery. ${ }^{1}$ The insertion of IUD immediately after cesarean delivery can reduce complaints during setup, however, there are several side effects after insertion. ${ }^{2,3}$ To our knowledge, studies regarding the side effects of IUD insertion after cesarean delivery is limited. We aimed to investigate the side effects of intracesarean IUD placement.

\section{METHODS}

This was a descriptive study. Subjects were all pregnant women who had $\mathrm{Cu}$ T380 IUD to beplaced after cesarean delivery at Prof. Dr. dr. R. D. 
Kandou Hospital during the period of August 2016 to September 2016. After the IUDs were placed, we would monitor the side effects for two weeks. The data obtained were recorded in a special form. All statistical analysis was performed using SPSS 20 for windows. A p value of $<0.05$ was considered statistically significant. McNemar test was used to compare paired dichotomous, categorical variables.

\section{RESULTS}

A total of 52 subjects were recruited in this study. $43(82.69 \%)$ of the subjects were in the age group of 20-35 years, $36(69.24 \%)$ subjects were multiparous, 27 (51.92\%) graduated from senior high school (Table 1).

Table 1. Characteristics of Research Subjects

\begin{tabular}{lcrc}
\hline \multicolumn{1}{r}{ Variables } & & N & \% \\
\hline Age & $<20$ & 3 & 5.76 \\
& $20-35$ & 43 & 82.69 \\
& $>35$ & 6 & 11.54 \\
Primiparous & & 16 & 30.76 \\
Multiparous & 36 & 69.24 \\
Elementary School & 2 & 3.84 \\
Junior High school & 5 & 9.61 \\
Senior High School & & 27 & 51.92 \\
Scholar & & 18 & 31.61 \\
\hline \hline
\end{tabular}

On the $7^{\text {th }}$ day, $49(94.23 \%)$ and $51(98.07 \%)$ subjects complained of abdominal pain and vaginal bleeding, respectively. Whereas, on the $14^{\text {th }}$ day, 48 (92.3\%) and 50 (96.1\%) subjects had abdominal pain and vaginal bleeding, respectively. We found significant decreases in both complaints on the $14^{\text {th }}$ day, compared to the $7^{\text {th }}$ day. $(\mathrm{p}<0.05$ and $\mathrm{p}<0.05$, respectively).
Table 3. The Acceptance of Side Effects of the Insertion

\begin{tabular}{|c|c|c|c|c|c|}
\hline \multirow{2}{*}{$\begin{array}{l}\text { Acceptance of } \\
\text { Side Effects }\end{array}$} & \multicolumn{2}{|c|}{ Day $7^{\text {th }}$} & \multicolumn{2}{|c|}{ Day $14^{\text {th }}$} & \multirow{2}{*}{$p$ value } \\
\hline & $\mathbf{N}$ & $\%$ & $\mathbf{N}$ & $\%$ & \\
\hline Yes & 51 & 98.07 & 51 & 98.07 & \multirow{2}{*}{$>0.05$} \\
\hline No & 1 & 1.92 & 1 & 1.92 & \\
\hline
\end{tabular}

$51(98.07 \%)$ subjects accepted the IUD. There were no signicant difference between acceptance on day $7^{\text {th }}$ and $14^{\text {th }}(p>0.05)$.

\section{DISCUSSION}

IUD has many advantages compared to other contraceptives. IUD has long-term effectiveness, and it only requires one installation. Moreover, it is relatively affordable. The weakness of this method is the side effects during and after placement. The side effects of IUD insertion including bleeding, abdominal pain, expulsion influence the decision to keep using IUD as a contraceptive method. The acceptors are reluctant to use IUD because they are afraid of the side effects. ${ }^{4,5}$

In this study, $82.69 \%$ of IUD acceptors were in the age group of 20-30. This finding is similar to previous studies. Juliaan and Maria reported that $86 \%$ postpartum contraceptive users were in the age group of $25-29$ years (86\%). ${ }^{6}$ Jurisman et al found that most of IUD users IUD were in the age group of 20-35 years. ${ }^{7}$

Bleeding and abdominal pain are the side effects that are caused by the reaction in the endometrium plasminogen. Nidhi et al found that on intracesarean IUD, 15 subjects had bleeding, while $88 \%$ had only mild pain. ${ }^{8}$

Chi et al stated that the incidence of expulsion was $4.1 \%$ in intracesarean IUD insertion. ${ }^{9}$ Friadi found the expulsion rate was $5 \% .{ }^{10}$ Manju revealed

Table 2. Side Effects of Intracesarean IUD Insertion

\begin{tabular}{|c|c|c|c|c|c|c|}
\hline \multicolumn{2}{|c|}{ Variables } & \multicolumn{2}{|c|}{ Day $7^{\text {th }}$} & \multicolumn{2}{|c|}{ Day $14^{\text {th }}$} & \multirow{2}{*}{ p value } \\
\hline & & $\mathbf{N}$ & $\%$ & $\mathbf{N}$ & $\%$ & \\
\hline \multirow{2}{*}{ Abdominal Pain } & Yes & 49 & 94.23 & 48 & 92.3 & \multirow{2}{*}{$<0.05$} \\
\hline & No & 3 & 5.76 & 4 & 7.64 & \\
\hline \multirow{2}{*}{ Vaginal bleeding } & Yes & 51 & 98.07 & 50 & 96.1 & \multirow{2}{*}{$<0.05$} \\
\hline & No & 1 & 1.92 & 2 & 3.84 & \\
\hline
\end{tabular}


that the expulsion rate of women who gave birth by vaginal delivery was $1-7 \% .{ }^{4}$ In this study, there were 2 cases with expulsion, which occurred on day 7 (1.92\%) and day 14 (1.92). Expulsion maybe caused by several factors such as the distance IUD on the endometrium, extensive uterine cavity in twin pregnancies and the process of uterine involution.

Knowledge and understanding of the advantages and disadvantages of the IUD is still low. Vaginal bleeding and abdominal pain are side effects that often cause a person to stop using IUD. Bleeding is the highest reason to discontinue the usage of IUD. An understanding of the side effects including bleeding is of course related to the initial counseling when the acceptor will decide to use the IUD. In a study conducted by Satyavathiin 1000 women using IUD, $27.27 \%$ and $9.09 \%$ of them discontinued the usage of IUD due to bleeding and abdominal pain, respectively. ${ }^{11}$ Setijanto found the AKDR CuT380 acceptance and effectiveness for 6 months were $86.8 \%$ and $100 \%$ with expulsion rate of $12.6 \%$. There were also other side effects such as vaginal discharge, menstrual pain and spotting. ${ }^{12}$ In this study, the acceptance of the side effects of IUDs on both the $7^{\text {th }}$ and $14^{\text {th }}$ day were $98.07 \%$. Bleeding that occurs in this study is spotting and abdominal pain category degrees of mild to moderate. Based on the number of cases there were only two acceptors that were not satisfied with the use of IUD due to expulsion.

\section{CONCLUSION}

The acceptance of side effects by the acceptor reaches $100 \%$, with the incidence of early postpartum expulsion is $3.8 \%$. The side effects of IUD are minimal.

\section{REFERENCES}

1. Situasi dan Analisis Keluarga Berencana. Diterbitkan oleh Kementrian Kesehatan RI Pusat Data dan Informasi. 2014. http://www.depkes.go.id/folder/view/01/structure-publi kasi-pusdatin-info-datin.html

2. Proyeksi pertumbuhan penduduk menurut provinsi 20102035. Diterbitkan oleh Badan Pusat Statistik. 2009.

3. Pusat Penelitian dan pengembangan KB-KS. Kajian Implementasi Kebijakan Penggunaaan kontrasepsi IUD 2011: 1-3.

4. Amelia M, Wahyono K. Penggunaan Alat Kontrasepsi Pascamelahirkan. Puslitbang KB dan Kesehatan Reproduksi Badan Koordinasi Keluarga Berencana Nasional. Jakarta 2009.

5. Irving S, Forrest G, Frederick S, Sandra N. The Copper T 380 Intrauterin Device, the Population Council. 1992: 7-32.

6. Juliaan F, Maria A. Penggunaan Kontrasepsi pada Perempuan Pascamelahirkan dan Pascakeguguran, Se DKI 2012. Pusat Penelitian dan Pengembangan Kependudukan, BKKBN 8 Juni 2015.

7. Jurisman A, Ariadi, Kurniati R. Hubungan Karakteristik Ibu dengan Pemilihan Kontrasepsi di Puskesmas Padang Pasir Padang. J Kes Andalas. 2016; 5(1): 1-5.

8. Nidhi M, Neelesh D, Vrunda J. Intrauterine Device Insertion during Caesarean Section - A Boon for Rural Women. IOSR J Dental Med Scien, 2013; 8(3): 21-3.

9. Chi IC, Wen ZS, Balogh S, Ng K. Post-Cesarean Section Insertion of Intrauterine Devices AJPH, 1984; 74(11).

10. Ginting FS. Pemasangan AKRD CuT-380A saat seksio sesaria di RSUP Prof. Dr. R. D. Kandou. Manado: Universitas Sam Ratulangi, 2012.

11. Maluchuru S, Aruna V, Prabhavathi N. Post Partum Intrauterine Device Insertion 2 yr Experience at a Tertiary Care Center in Guntur Medical College/Govt. General Hospital, Guntur. IOSR J Dental Med Scienc (IOSR-JDMS). 2015; 14: 56-61.

12. Setijanto IT. AKDR CuT380A pascaplasenta: penerimaan, efektivitas dan efek samping. Universitas indonesia. Program studi obstetri dan ginekologi: Jakarta 2014. 